\title{
The Unwritten Ritual: The Duality of Religion in Sixteenth-Century Chosŏn Korea
}

\author{
Soyeon Kim
}

\section{1 \\ Introduction}

Visual materials often show things that are not seen in textual records. Buddhist paintings produced during the Chosŏn dynasty of Korea (1392-1910), whose state religion was Confucianism, constitute such visual materials. Buddhism, which had been the state religion and ruling ideology for more than eight centuries on the Korean peninsula, was considered a vestige of earlier dynasties by the founders of the Chosŏn reign, Confucian scholars. So it was natural that they try to erase the influence of Buddhism in their new dynasty. Given these circumstances, Chosŏn Buddhist paintings reveal not only the tension and conflict that existed between the two different ideologies - Confucianism and Buddhism - but also their recombination and coexistence, which are rarely discussed in historical texts from the time.

This paper aims to provide an explanation of how a Buddhist painting's patron and its iconography are intertwined with such a situation, focusing on a hanging scroll entitled Gathering of the Four Buddhas [Fig. 6.1] produced in 1562. First of all, I will examine the possibility that the painting was used for a mortuary ritual by considering its inscription. Then, I will look at historical shifts in the iconography of the Four Buddhas. I will provide an explanation as to how its newer meaning was deeply embedded in the ritual culture of the Chosŏn period. Lastly, this paper will investigate the historical context of several political and religious events that played a significant role in the genesis of this work. Treating the importance of the painting within the specific context of Buddhist rituals and patronage, against the background of parallel Confucian thought, will illuminate the complexity of religious and visual culture in sixteenth-century Chosŏn Korea, where official proscriptions against Buddhism were often ignored in the context of domestic devotion.

(C) SOYEON KIM, 2019 | DOI:10.1163/9789004375888_008

This is an open access chapter distributed under the terms of the prevailing CC-BY-NC-ND License at the time of publication. 


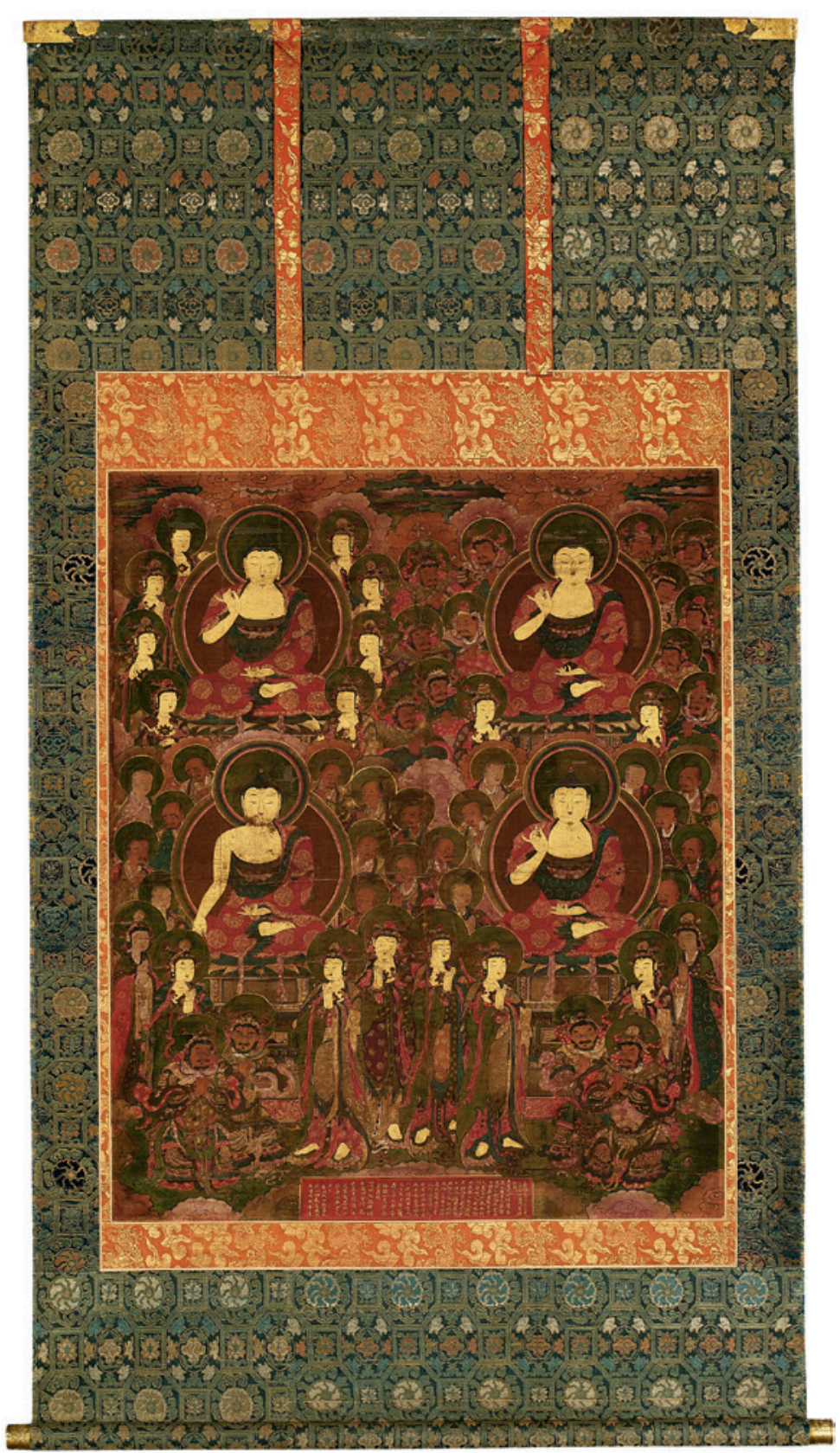

FIGURE 6.1 Anonymous, Gathering of the Four Buddhas (1562). Colours on silk, $90 \times 74 \mathrm{~cm}$. National Museum of Korea IMAGE (C) NATIONAL MUSEUM OF KOREA 
The inscription of Gathering of the Four Buddhas, now in the National Museum of Korea, indicates that the painting was commissioned by Yi Chongnin (15381611) for the well-being of his late maternal grandfather, Kwŏn Ch'an (?-1560), in the afterlife. As one of only a few privately commissioned religious works showing the commissioner's intention explicitly, this painting provides vivid material evidence of someone's death and his grandson's mourning. Apart from the painting, however, there remains another historical document in connection with Kwŏn's death. According to Chosŏn wangjo sillok (Veritable Records of the Chosŏn Dynasty), which is an official chronological record of Chosŏn kings' historical reigns, the Chosŏn Minister of Finance Kwŏn Ch'an died on the twenty-seventh day of the ninth month in 1560 . In the entry of the next day, it is written that Prince Tŏgyang (Yi Ki, 1524-1581), Kwŏn's son-in-law, had an audience with his half-brother, King Myŏngjong (r. 1545-67). Prince Tŏgyang wanted to ask the king to allow his son, Yi Chongnin, to hold funeral rites for the deceased Kwŏn Ch'an. Courtiers fiercely opposed the prince's proposal. At that time, it was forbidden for the son of one's daughter to play the role of chief mourner at a funeral, because it was considered to be against Confucian principles, and further, to be a Buddhist custom. According to Confucian dogma, only the son and heir of a family could be the chief mourner at funerals for ancestors. Moreover, Yi Chongnin was a grandson of the former King Chungjong (r. 1506-44). As a member of the royal family, he was expected to avoid acting in inappropriate ways, including serving as the heir for other families. Despite much opposition, however, King Myŏngjong acquiesced to the prince's wish, and the issue was never mentioned again. ${ }^{1}$

As one of two different responses to the death of Kwŏn, this entry from Chosŏn wangjo sillok offers an interesting case in the sense that it is not easy to examine the context surrounding a Buddhist work through an official document produced by the Confucian court, even though the painting is not mentioned. That is, two different media - a painting and a official written document - convey different stories about a historical figure who had to face his grandfather's death, and neither one mentions or even implies any reference to the other.

1 Myŏngjong Sillok [Veritable Records for the Reign of Myŏngjong] (1506; reprint, Seoul: 198587) 109-110. All the articles from the Sillok quoted in this paper are based on the version that had been stored at the archive in Mt. T'aebaek. 


\section{Second Mortuary Ritual}

Gathering of the Four Buddhas depicts four Buddhas preaching. Due to the colourful pigments, including gold, and meticulously depicted figures, it recalls the stylistic hallmarks of Buddhist painting from the previous dynasty, the Koryŏ (918-1392). However, we should focus on its inscription first, because, as we shall see, some words used here imply that the painting was produced for a Buddhist ritual. The inscription reads as follows:

\section{嘉靖壬戌六月日豊」山正李氏謹竭哀悼」伏爵」先考同知權贊㶾 」駕淑媛李氏靈駕」牧使朴諫兩位靈駕」女億春靈駕男李」氏靈 駕共脫生前」積衆之因同證」死後修九品之果現」存祖母貞敬夫 人尹」氏保体德陽君兩」位保体成詢兩位」保体小主朴氏保体」 李氏伯春保体李」氏敬春保体李氏」連春保体各離灾」殊俱崇福 壽亦虏」已身時無百害之」灾日有千祥之慶」壽不中大黃若」無 疆以眞黃金」新畫成」西方阿爾陀佛一幀」彩畫四會幀一面」彩 畫中壇幀一面」造安咸昌地上」院寺以奉香火」云尔」願以此功 德普及 $\lrcorner$ 於一切我等與衆 $\lrcorner$ 生皆共成佛道}

In an Imsul year, or the year of Kajŏng, in the sixth month, P'ungsanjŏng Yi mourns the death of his late father, Kwŏn Ch'an, along with Royal concubine Yi, Pak Kan and his wife, their daughter Ŏkch'un, and Gentleman Yi. May all of them reach the state of nirvana so they can recognize the causes of their misdeeds in their lifetime and become reborn in the nine grades of the pure-land afterlife. May the living grandmother Lady Yun, Prince Tŏgyang and his wife, Sŏng Sun and his wife, Young Master Pak and his wife, Yi Paekch'un, Yi Kyŏngch'un, and Yi Yŏnch'un stave off disaster and live out their allotted span of life. Further, may you live a long life while hundreds of disasters are averted time and again, and thousands of happy occasions continue day by day. We spent gold to make new paintings: a Western Amitābha painting, a coloured four [Buddhas]'s gathering painting and a coloured middle altar painting. We sent these paintings to Sang'wŏn Monastery in the Hamch'ang region. May all the merit be spread to each and all the living beings, and I hope that all living beings and I, myself, will jointly accomplish the Buddhist way. ${ }^{2}$

2 The translation is the author's own. 
In this inscription 'P'ungsanjŏng Yi' refers to Yi Chongnin. According to the inscription, Gathering of the Four Buddhas was produced alongside a 'Western Amitābha painting' and a 'middle altar painting'. That is, the painting was not created as a single work, but as one of a set of three paintings. Of the set, the latter two paintings have been lost. Noteworthy here is the fact that the last painting is called the 'middle altar painting' while the other two paintings are named after their subjects: 'Western Amitābha', meaning 'Amitābha Buddha of Western pure land', and 'Four [Buddhas]'s gathering'.

During the Chosŏn dynasty, Buddhist rituals were based on three altars: the upper altar, middle altar, and lower altar. Each altar could be built separately in different halls or together in a single hall within a monastery. Although the origin of the triple altar setting is unknown, the earliest document concerning the three altars is from the late fourteenth century, and the practice is believed to have become widely used in Buddhist ceremonies from the sixteenth century at the latest. ${ }^{3}$

The roles and characteristics of each of the three altars were different. The altars were dedicated to different deities. Although the manner of deciding the subjects of each altar varied according to period, region, and rituals, the upper altar was used mostly for the highest deities, such as Buddha or Bodhisattvas, while the middle altar was for deities lower than those of the upper altar. The lower altar was dedicated to dead spirits and deities who govern the underworld or who take care of the dead, such as Amitābha Buddha and his attendants. ${ }^{4}$ Buddhist ritual manuals published in the Chosŏn period record the subjects of the three altars as shown in the following table.

3 In Yangch'onjib, Kwŏn Kŭn, a scholar of the early Chosŏn period recorded an article about the Chin'gwan Monastery built for the rite for deliverance of creatures of water and land. According to the text, the arrangement of the halls of the Chin'gwan Monastery was designed based on the 'three altar manner'. Kwŏn Kŭn, "Chin'gwansa Suryuksa Chosŏngki", in Kwŏn Kŭn, Yangch'onjib [Collected Works of Yangch'on] (Chinju, Kwŏn Ju:1674; reprint, Seoul: 1978).

4 Many researchers have explained the object of worship at each altar differently. Hong Yunsik has suggested that the upper altar is for both Buddha and the Bodhisattvas, while Yu Mari has said that the Bodhisattvas were the object of the middle altar. The reason for the differences might have been the flexibility in the iconography of the three altars. Hong Y., Han'guk purhwa ŭi yŏn'gu (Seoul: 1980); Yu M., "Chosŏnjo ŭi t'aenghwa", in Kim Y., Chosŏn purhwa (Seoul: 1984) 188-204. 
TABLE 6.1 Three altars prescribed in the Buddhist ritual manuals published in the Chosŏn period

\begin{tabular}{|c|c|c|c|}
\hline $\begin{array}{l}\text { Buddhist Ritual } \\
\text { Manual }\end{array}$ & Upper altar & Middle altar & Lower altar \\
\hline $\begin{array}{l}\text { 『水陸無遮本等齋儀 } \\
\text { 撮要』 } \\
\text { (1573, Tŏkchu } \\
\text { Monastery) }\end{array}$ & $\begin{array}{l}\text { Countless } \\
\text { Buddhas and } \\
\text { Sages }\end{array}$ & $\begin{array}{l}\text { Three Realms and } \\
\text { the Four Palaces }\end{array}$ & $\begin{array}{l}\text { Underworld and the } \\
\text { Realm of Ghosts }\end{array}$ \\
\hline $\begin{array}{l}\text { 『法界聖凡水陸勝會 } \\
\text { 修齋儀軌』 } \\
\text { (1573, Kongnim } \\
\text { Monastery) }\end{array}$ & $\begin{array}{l}\text { Countless } \\
\text { Buddhas and } \\
\text { Sages }\end{array}$ & $\begin{array}{l}\text { Devayana } \\
\text { Avalokiteśvara, } \\
\text { Dhranimdhara, } \\
\text { and Kșitigarbha }\end{array}$ & $\begin{array}{l}\text { Amitābha } \\
\text { Avalokiteśvara, and } \\
\text { Mahāsthāmaprāpta }\end{array}$ \\
\hline $\begin{array}{l}\text { 『預修十王生七齋儀 } \\
\text { 纂』 } \\
\text { (1576, Kwanghŭng } \\
\text { Monastery) }\end{array}$ & $\begin{array}{l}\text { Three Bodies } \\
\text { of the Buddha }\end{array}$ & $\begin{array}{l}\text { Kṣitigarbha and } \\
\text { Demon King } \\
\text { No-poison }\end{array}$ & $\begin{array}{l}\text { Śakra and Four } \\
\text { Heavenly Kings }\end{array}$ \\
\hline $\begin{array}{l}\text { 『天地溟陽水陸齋儀 } \\
\text { 纂要』 } \\
\text { (1694, Hae'in } \\
\text { Monastery) }\end{array}$ & $\begin{array}{l}\text { Countless } \\
\text { Buddhas and } \\
\text { Sages }\end{array}$ & $\begin{array}{l}\text { Three Realms and } \\
\text { the Four Palaces } \\
\text { (Devayana } \\
\text { Avalokiteśvara, } \\
\text { Dhranimdhara, } \\
\text { and Kṣitigarbha) }\end{array}$ & $\begin{array}{l}\text { Underworld and the } \\
\text { Realm of Ghosts } \\
\text { (Amitābha } \\
\text { Avalokiteśvara, and } \\
\text { Mahāsthāmaprāpta) }\end{array}$ \\
\hline $\begin{array}{l}\text { 『冊補梵音集』 } \\
\text { (1713, Pohyŏn } \\
\text { Monastery) }\end{array}$ & $\begin{array}{l}\text { Vairocana } \\
\text { (Pirosana), } \\
\text { Vairocana } \\
\text { (Nosana), and } \\
\text { Sākyamuni }\end{array}$ & $\begin{array}{l}\text { Buddhas of the } \\
\text { ten directions, } \\
\text { Dharma of the } \\
\text { ten directions, } \\
\text { and Sangha of } \\
\text { the ten directions }\end{array}$ & $\begin{array}{l}\text { Amitābha, } \\
\text { Avalokiteśvara, and } \\
\text { Mahāsthāmaprāpta }\end{array}$ \\
\hline $\begin{array}{l}\text { 『天地冥陽水陸齋儀 } \\
\text { 梵音刪補集』 } \\
\text { (1723, Unknown) }\end{array}$ & $\begin{array}{l}\text { Vairocana } \\
\text { (Pirojana), } \\
\text { Vairocana } \\
\text { (Nosana), and } \\
\text { Śākyamuni }\end{array}$ & $\begin{array}{l}\text { Devayana } \\
\text { Avalokiteśvara, } \\
\text { Dhranimdhara, } \\
\text { and Kṣitigarbha }\end{array}$ & $\begin{array}{l}\text { Amitābha, } \\
\text { Avalokiteśvara, and } \\
\text { Mahāsthāmaprāpta }\end{array}$ \\
\hline
\end{tabular}


As seen in the table, the objects of worship for each altar in the Buddhist ritual manuals followed a general pattern. These details were applied flexibly and the dedications could vary but most of the deities seen in the table were generally worshipped and so could be consecrated for any reason.

When a Buddhist ceremony was held, people enshrined Buddhist paintings as objects of worship, like Buddha statues. As a result, the concept of the three altars for Buddhist ceremonies was also applied to Buddhist paintings. Each of these paintings was called sangdan-t'aeng (upper altar painting), chungdant'aeng (middle altar painting), or hadan-t'aeng (lower altar painting). Just as the dedications of the three altars were changeable, the themes of these paintings were not fixed either. Because the titles of altar paintings were based on function rather than theme, a variety of Buddhist deities could be depicted in the images.

The fact that Gathering of the Four Buddhas is a painting from a set of three, and that one among them is referred to as a 'middle altar painting' suggests that all three paintings functioned as ritual paintings, even though two paintings are not explicitly called 'altar painting. ${ }^{5}$ If the three paintings were designed for three altars, Gathering of the Four Buddhas could have been an upper altar painting because the Four Buddhas often means 'Countless Buddhas'. The 'Western Amitābha painting' might have been the lower altar painting. In other words, the term 'middle altar painting' used in the inscription implies that these paintings were destined for a kind of ritual. And due to the inscription saying that the painting was for the late Kwŏn Ch'an, it is highly probable that the rite for the salvation of Kwŏn Ch'an was held two years after his death, when the painting was produced, and that the paintings, including Gathering of the Four Buddhas, were used for this rite.

An expression quoted in the inscription provides further evidence that the painting was used for a Buddhist rite. In the inscription the names of the dead and the living are listed, along with a blessing for each of them. Among these, it is worth noting the following: 'hundreds of disasters are averted time and again, and thousands of happy occasions continue day by day' This phrase appears to be just an ordinary prayer for fortune and peace. However, it is noteworthy that this phrase is still used in Korean Buddhist ceremonies even in modern times. The oldest known example of this sentence can be found in Na'am chapchŏ (The Miscellaneous Works of Na'am) written by monk Pou (penname

5 While many paintings called 'chungdan-t'aeng' in their inscription remained, paintings named 'sangdan-t'aeng' or 'hadan-t'aeng' are very few in number for an unknown reason. In case of the latter, paintings were named after their theme. 
Na'am, 1509-1565). We can find the phrase in his ceremonial works, including the 'Oral Text Read in the Ritual for the Repairing of the Pong'unn Monastery' and the 'Oral Text Read in the Ritual for the Salvation of King Injong'. This phrase was not often quoted in other contemporary works, but it came to be used frequently in later works such as Samyŏngdang taesajip (1652), Pŏmŭmjip (1723) and Sŏngmun üibŏm (1936).

From the sixteenth to the twentieth century, from Na'am chapchŏ to Sŏngmun üibŏm, this phrase was used in the same context, with very few changes to its original form. That is, the phrase appeared only in ceremonial situations. It is unclear whether Pou created the phrase or quoted it from other documents that no longer exist. However, judging from the fact that Pou was the most influential monk in sixteenth-century Chosŏn Korea, and was supported by the Queen Dowager Munjŏng, 'Pou's phrase' may well have become an idiom.

Ultimately, the phrase was recorded in Buddhist ceremony manuals which are still used to this day. Yet Gathering of the Four Buddhas is the only extant example in which Pou's phrase is included in the inscription of a painting. Given the fact that this ceremonial phrase was written on a painting, the painting seems thereby to be closely related to Buddhist ritual. The writer of the inscription may have referred to other inscriptions and contemporary oral ritual texts. Because Gathering of the Four Buddhas was a court painting ordered by a member of the royal family, it is not difficult to imagine that the writer of the inscription working for the court could easily access the texts for rituals written by Pou, who at one time enjoyed the support of the court. It may also mean that the painting was used in a ceremonial context.

In sum, the inscription suggests that the painting was used during a second ritual for Kwŏn Ch'an. Thus, the funeral, which was a source of controversy at court, was held right after Kwŏn's death, while the Buddhist rite for Kwŏn's salvation was held two years later. The second ritual left its mark on the inscription, but not in official historical records.

\section{$4 \quad$ Four Buddhas in Korean History}

We can also ascertain the situation surrounding the creation of the painting and its ceremonial uses by examining the subject of the painting itself. Although religious images are generally recognized and produced on the basis of religious scriptures, the iconography of a Buddhist artwork does 
not always closely follow the Buddhist scriptures. Sometimes iconographic transformation happens in response to changes in the worshippers' actual beliefs that prevail over orthodox principles. Buddhist ritual manuals can be perceived as evidence of this phenomenon. ${ }^{6}$

The subject of Gathering of the Four Buddhas is an interesting case that can be explained by ritual manuals rather than orthodox documents. The topic of the painting is the 'Four Buddhas'. In the upper left section we see Amitābha Buddha, surrounded by Eight Bodhisattvas. ${ }^{7}$ Bhaișajyaguru Buddha, holding a medicine case, is seated on the upper right, and Saakyamuni Buddha with his ten disciples is depicted on the lower left side of the painting. The Buddha in the lower right side does not have any specific attributes or gestures that would give us a clue to his identification. Through comparison with other paintings and sculptures, the assumption that this Buddha is Maitreya Buddha, who is the future Buddha, has commonly been accepted. ${ }^{8}$

The theme of the Four Buddhas, composed of Amitābha, Bhaișajyaguru, Śākyamuni, and Maitreya, has a long tradition in Korean art. The composition started to appear in the sixth century, as seen in the Buddhas facing in four cardinal directions such as Four-sided Buddha (四面佛) [Fig. 6.2]. ${ }^{9}$ It seems that Four-sided Buddha is a non-orthodox icon that has nothing to do with an orthodox scripture, but has an unknown alternative source. The notion of Four Buddhas continued until the early Chosŏn period, as attested by various contemporary historical documents. ${ }^{10}$

6 Most of the Buddhist ritual manuals that I would like to refer to as evidence in this paper were published in the late Chosŏn period. These manuals are the embodiment of many actual Buddhist rituals formed and developed over hundreds of years; they not only reflect the characteristics of worship of the past and of contemporaneous times, but have also served as the standard-bearers of Buddhist rituals to this day.

7 Bodhisattva is the term for someone who pursues awakening. In the Buddhist pantheon, as high deities but lower than Buddha, Bodhisattvas are often depicted as attendants of Buddha. Eight Bodhisattvas comprised of Mañjushri, Avalokiteśvara, Vajrapāni, Maitreya, Kșitigarbha, Ākāśagarbha, Sarvanīvaraṇaviṣkambhin, and Samantabhadra are one of the attributes of Amitābha Buddha.

8 The unidentified Buddha is Maitreya Buddha, as is evident from similar works such as Gathering of six Buddhas housed in Sairai Monastery in Japan, and this is the commonly accepted view. National Museum of Korea, Pleasant Encounter with Recently Acquired Collections (Seoul: 2000) 194; Pak Ŭ., Chosŏn chŏngi purhwa yŏn'gu (Seoul: 2008) 77.

9 It is different from the Buddhas of the Four Directions (四方佛), associated with the Vajrasekhara Sutra.

10 According to Yangch'onjib, written in the fifteenth century, there was a mountain called 'Sabul' (Four Buddhas) in Kyŏngsang Province in the fourteenth century. The mountain was named after a cube-shaped stone carved with four Buddhas on each side located on top of the mountain. Also, an anthology of the fifteenth century titled Tongmunsŏn 


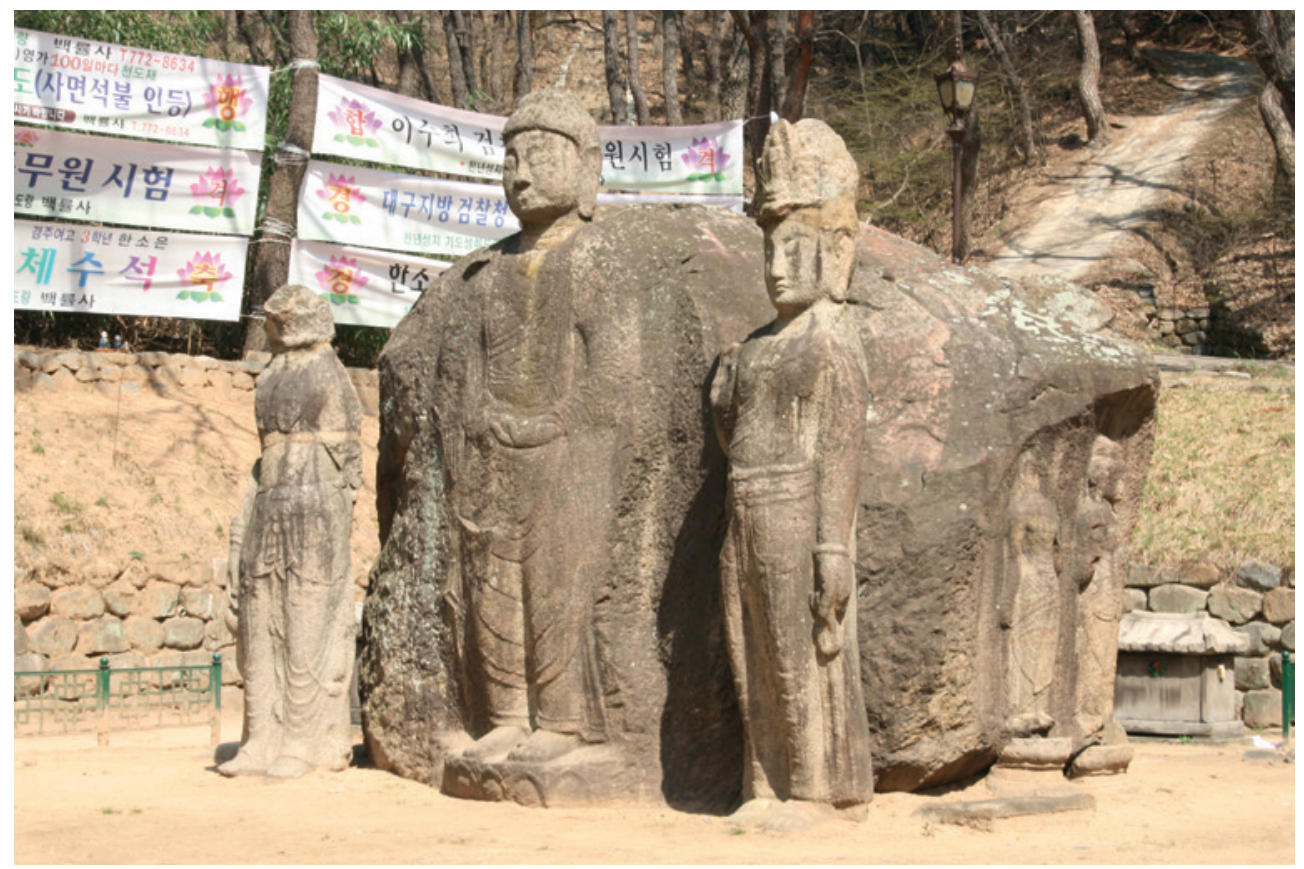

FIGURE 6.2 Anonymous, Stone Buddhas in Four Directions at Kulbul Monastery Site (Unified Silla Period). Height 350 cm. Kyŏngju, Korea

PHOTO TAKEN BY THE AUTHOR

When it comes to examples from the sixteenth century, however, the characteristics of the Four Buddhas as directional Buddhas have largely disappeared, as we see in the Gathering of the Four Buddhas, whose main Buddhas are placed without regard for the four cardinal directions. A set of four hundred Buddhist paintings which were painted at about the same time as Gathering of the Four Buddhas is another example bearing witness to this tendency. In 1565, the Queen Dowager Munjŏng, the mother of King Myŏngjong, supported a Buddhist project for her dead grandson Sunhoe, who had been the crown prince. Hoping for the late prince's comfort in the afterlife, the birth of a new prince and peace in the royal family, the Queen ordered the production of four hundred Buddhist paintings. These four hundred paintings included a hundred Amitābha paintings, a hundred of Bhaiṣajyaguru, a hundred of

illustrates the pagoda of Anyang Monastery where the four sides of the inner walls were decorated with four Buddhas. "Sabulsan Mirŭksa chungch'ang'gi", in Kwŏn, Yangch'onjib; "Kŭmju Anyangsa t’ap chungsin'gi”, in Sŏ Gŏjŏng et al., Tongmunsŏn (1478; reprint, Seoul: 1968). 
Śākyamuni, and a hundred paintings of Maitreya. ${ }^{11}$ The paintings were used for court-sponsored Buddhist rites and were then distributed all over the country. One of the characteristics of these four hundred paintings that differs from prior Buddhist art representing the four Buddhas is that there is no visual indication of directions. Taken as a whole, the four hundred paintings depict the Four Buddhas. However, the Four Buddhas are not painted on one scroll, but as individual paintings depicting a Buddha flanked by two Bodhisattvas [Fig. 6.3]. That is, once they had been distributed and enshrined at different monasteries, any clue as to their identity as the Four Buddhas disappeared. Each was seen as an individual painting showing an assembly of a Buddha.

This way of visualizing the Four Buddhas differs significantly from earlier representations, such as the stone relief from the sixth century, which includes features indicating directional alignment by depicting four Buddhas on each face of a cube-shaped space [Fig. 6.2]. The Four Buddhas, originally placed on three-dimensional objects and representing the spatial orientation of the iconography, gradually started to appear in two-dimensional works, and, finally, were separately depicted on single paintings. This means that the directional aspect of the Four Buddhas, projecting their divinity outwards, was ultimately diminished. Rather, by sending these paintings to Buddhist monasteries all over the country, Queen Dowager Munjŏng used them as a means of demonstrating another meaning of these icons; spreading the four hundred Buddha's 'pure lands' reveals the notion of multi-Buddha: that there are myriad Buddhas in myriad lands.

The image of Four Buddhas underwent an expansion in its meaning during the Chosŏn period. This shift in meaning from the Buddha facing in four directions to multi-Buddhas is reflected in Buddhist ritual manuals of the late Chosŏn period. Each name of the Four Buddhas is referred to in these records, such as Hyŏnhaeng pŏp'oe yech'am ŭisik (1709) and Chakpŏp kwigam (1827), as texts to be orally recited. According to these texts, the Four Buddhas were recited in the context of certain ceremonial events: for example, when holding a

11 Of the four hundred paintings, only six remain in existence today. The original number of paintings is known due to the inscriptions on the paintings. According to Myŏngjong Sillok, Much'a taehoe or Ceremony of Giving Alms to all the Assembly including monks and laymen was held in commemoration of the repairs done to Hoe'am Monastery. Myŏngjong Sillok 40. It is suggested that the monastery was embellished with the four hundred paintings. 


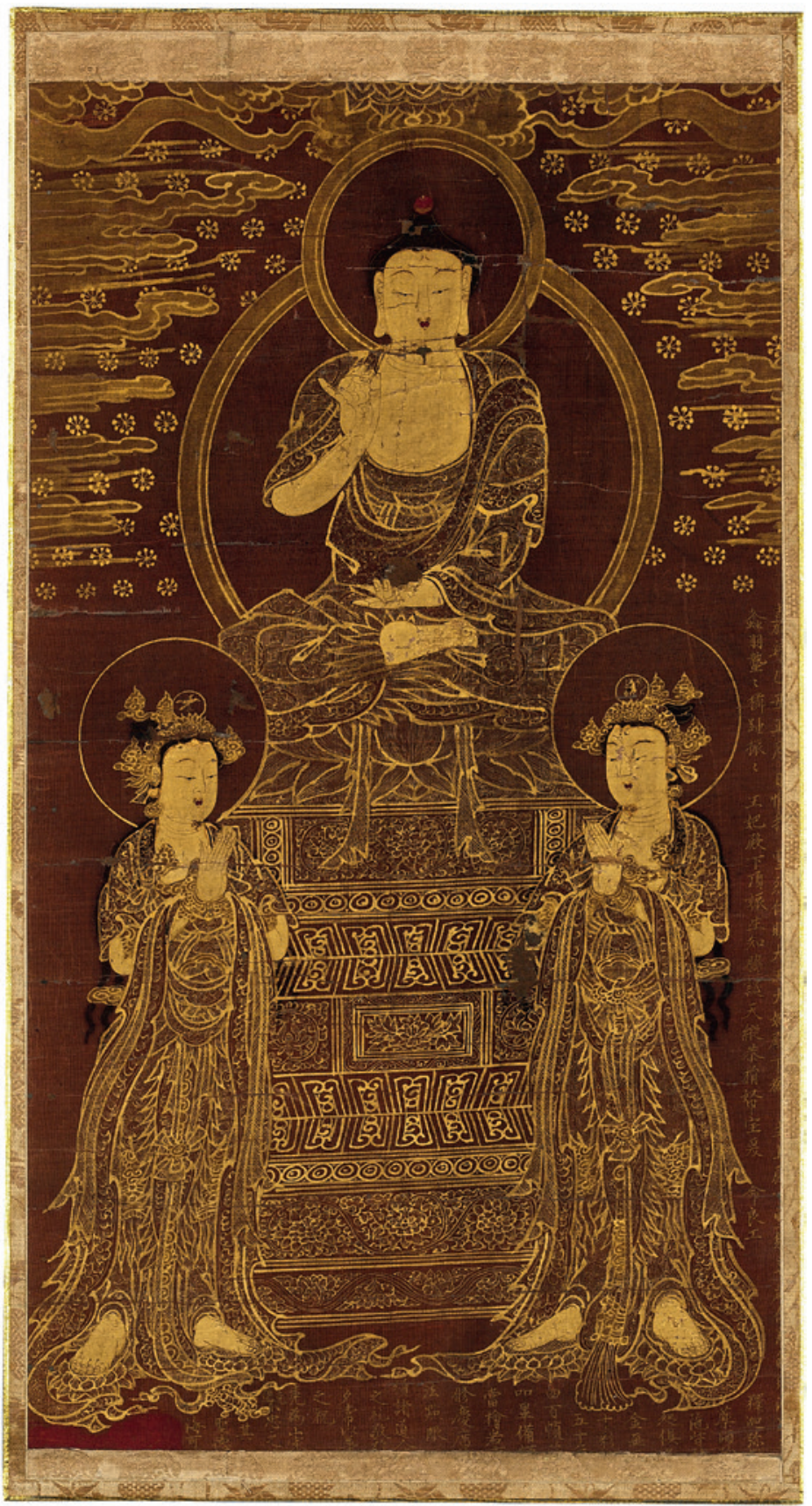

FIGURE 6.3 Anonymous, Bhaișajyaguru Triad (1565). Gold on silk, $54.2 \times 29.7 \mathrm{~cm}$. National Museum of Korea IMAGE (C) NATIONAL MUSEUM OF KOREA 
ceremony on the first day of the new year, or when listing the commandments of Buddhism. At the time, devotees recited the names of various deities, respecting their hierarchical position:

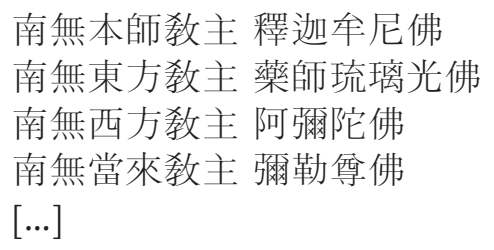

Homage to the original teacher, Sākyamuni Buddha.

Homage to the master of the Eastern region, the Radiance of Glass

Bhaișajyaguru Buddha.

Homage to the master of the Western region, Amitābha Buddha.

Homage to the future master, Maitreya Buddha.

$[\ldots]$

CHAKPOัP KWIGAM ${ }^{12}$

In the lists of deities that were recited like a mantra, the Four Buddhas Śākyamuni Buddha, Bhaișajyaguru Buddha, Amitābha Buddha, and Maitreya Buddha - were placed at the top. Subsequently, the names of another set of Twelve Buddhas (Ch'amje ŏpjang Sibijonbul) were recited. Names of other deities followed. In this context, the Four Buddhas are not simply the Buddhas representative of each cardinal direction, but the supreme deities recited first among all the different kinds of Buddhas extant in the universe and other Buddhist deities. In other words, the concept and meaning of the Four Buddhas underwent a transformation.

Indeed, in the late Chosŏn period, there were many forms of the Buddha representing Buddhas extending in all directions and across three periods of time. The long tradition of the Four Buddhas had become one of these forms. Specifically, the Four Buddhas were not the deities referred to in orthodox Buddhist scriptures, but were instead the non-orthodox deities that had been celebrated by public worship: popular belief had made possible an extension and transformation of the iconography. Viewed from this perspective, it is no wonder that the Four Buddhas became the subject of the upper altar rather than 'the Three Bodies of the Buddha' or 'Countless Buddhas and Sages' referred to in many ritual manuals. Various forms of multi-Buddhas could replace each other in multiple ways.

12 Paekp’a kŭngsŏn, Chakpŏp kwigam: Hanguk pulgyo chŏnsŏ, vol. 13 (Seoul: 1989) 583. 
As we have seen earlier, unlike the Four Buddhas of the past, they were at the time referred to in ritual manuals as the highest deities among many, whose names were recited by Buddhists during rituals. Considering the fact that the deity was familiar to many, it is possible that the Four Buddhas were a popular subject for ritual chanting for general prayers even before the Chosŏn period, although no evidence of this has come to light. However, the ritual manuals of the late Chosonn period are solid evidence revealing that the Four Buddhas, despite never having been documented in the Buddhist canon, were nonetheless included in more popular and practical forms of worship, through ritual. Consequently, conceptual and visual representation of the Four Buddhas was adapted in a flexible manner via the practices of Buddhist worship. Gathering of the Four Buddhas bears witness to this long-term transformation. In this regard, it seems probable that the Four Buddhas functioned as a main Buddha in ceremonies for the dead, which were the most popular Buddhist rituals in sixteenth-century Chosŏn.

'Following Confucianism in Public, Following Buddhism in Private'

Thus far, I have tried to reconstruct the specific context in which the second mortuary ritual held for Kwŏn Ch'an used Gathering of the Four Buddhas. At this point, the question can be raised: why did Yi Chongnin hold two different kinds of ceremonies for Kwŏn Ch'an, one Confucian, the other Buddhist? In order to answer this question, it is necessary to examine the religious and funerary practices of the Chosŏn period.

Confucianism was the reformist state ideology upon which the Chosŏn dynasty was founded. It is natural that many Chosŏn rulers adopted antiBuddhist policies to remove the influence of Buddhism as an old political power. For example, King T'aejo (r. 1392-98) expropriated the property and servants of Buddhist temples. Buddhist monks were barred from entering the capital city during the reign of King Sejong (r. 1418-50), and the state examination for Buddhist monks was abolished in the sixteenth century. Moreover, the various harmful effects of Buddhism were a subject of constant discussion among Chosŏn era intellectuals.

Nevertheless, many Chosŏn era historians today explain this period of antiBuddhist sentiment with the phrase, 'Following Confucianism in public, following Buddhism in private. ${ }^{13}$ This points to a situation where Confucianism

13 For example, Ch'oe C., "Chosŏn chŏn'gi chong'gyo honhap kwa panhonhapju'úi", Chong'gyo yŏn'gu 27 (2007) 37-81. 
was the official ideology of the state, but Buddhism still exerted considerable influence. Even Confucian scholar-officials who criticized Buddhism in public had an ambivalent attitude toward Confucianism and many practised Buddhism in private.

\section{向者卒左議政柳廷顯言於予日 水陸齋 偩誦經關內 甚爲不可 請 罷之 予從其言 師罷誦經 若水陸之設 其來向矣 不可遽革 予不 師從之 厥後廷顯臨終噣飯佛齋僧之費於其子璋 幾至五千餘石 人皆笑之今人於朝廷 則以禁神祀爲言 退家則惑於神祀者頗多.}

One day, the late first vice-premier Yu Chŏnghyŏn said to me, 'Holding the Suryuk-jae ritual [a rite for the deliverance of creatures of water and land] and chanting the Buddhist scriptures in the court should be prohibited [...]'. When Yu died, in his will he asked his son, Yu Chang, to make an offering to Buddha. Yu Chang then spent 5,00o bags of rice to hold a Buddhist ritual, so people laughed at him. Recently, there has been an increase in people like Yu, who claim that rituals for ghosts should be banned in the court, but who are obsessed with the issue privately. ${ }^{14}$

Such domestic beliefs were clearly visible in popular rituals. Although Confucianism held a dominant position in the dispute between Confucianism and Buddhism, Buddhist beliefs in general seem not to have suffered greatly, and many documents attest to the fact that any number of Buddhist rituals took place in the early Chosŏn period. ${ }^{15}$

Specifically, Buddhist rituals maintained considerable influence over funeral services for the dead. Throughout the ages, mortuary culture has been closely related to a culture's view of the afterlife or spirit. Of course, when a country's religion undergoes radical transformation, all things based on that religion, including views of the afterlife and mortuary culture, are also transformed. Sometimes such transformations are accelerated by the system of government and government policies. Yet changes usually occur at a very slow pace. Thus it was natural for early Chosŏn people to continue to hold Buddhist ceremonies for their ancestors and to make offerings to the temple as they had

\footnotetext{
14 Sejong Sillok [Veritable Records For The Reign of Sejong] (reprint, Seoul: 1970) 371. The translation is by the author.

15 The Sillok contain a great number of passages criticizing the holding of Buddhist rituals while other passages show that the court constantly tried to settle regulations concerning funerals. This reflects the phenomenon that people preferred Buddhist customs when holding funerals, contrary to official policy. In fact, people and even the royal family carried out Buddhist rituals.
} 
done during the Koryŏ period, hoping that their dead parents would be reincarnated in the Buddhist paradise. ${ }^{16}$ This situation resulted in an institutional encouragement of Confucian funeral rites and a crackdown on non-Confucian (Buddhist) funerals. ${ }^{17}$ For example, the Suryuk-jae ritual was abolished several times at court, and anything considered to be 'Buddhist in nature', like cremation, was prohibited (however, the Suryuk-jae ritual was frequently reinstated, and by the sixteenth century many people flouted the prohibition against cremation).

The dilemma surrounding religion and funerals was even a problem for the royal family. Despite the fact that the Chosonn court made Confucianism the official state ideology, royal family members constantly supported Buddhism. Some kings engaged in Buddhist projects, and queens and royal concubines often commissioned Buddhist paintings or held Buddhist rituals in the palace. These actions can be understood not only as a representation of the personal beliefs of particular rulers, but also as strategies to strengthen royal authority. Either way, these practices often sparked strong opposition from Confucian scholar-officials. ${ }^{18}$ Conflicts over Confucianism and Buddhism and confusion over the standard ideology lasted well into the late sixteenth century, and also affected the country's legal system. Thus, we can say that the sixteenth century, when Yi Chongnin wished to perform a funeral service for Kwŏn Ch'an, was a period of religious transition in which anti-Buddhist and pro-Buddhist notions coexisted, and different religions and ideologies took the initiative in different areas.

After all, Yi Chongnin held two funerals, both Confucian and Buddhist, for his maternal grandfather. Due to a lack of evidence, Yi Chongnin's personal beliefs and thoughts are unknown. Nonetheless, the existence of Gathering of the Four Buddhas shows that he was by no means free from the mixed religious culture of the time. Because of his actions, Yi Chongnin was called to account by the royal court, even in such a private area as a family member's funeral, because he, a member of the royal family, was required to follow

16 Regarding the situation where people tended to maintain their traditional religious attitude, the idea of Wendy Doniger who mentions the conservatism of ritual is worthy of reference: Doniger W., Other Peoples' Myths: The Cave of Echoes (reprint, Chicago: 1995) $125^{-126 .}$

17 See Han H., "Chosŏn chŏn'gi changne munhwa wa Kuihusŏ", Chosŏn sidaesa hakbo $3^{1}$ (2004) 39-78.

18 Sometimes, however, Buddhist practices were combined with notions of loyalty or filial piety, and could thus be considered a way to support Confucian ideology. For Buddhist art and its Confucian meaning, see Kang H., "Chosŏn chŏn'gi pulgyo wa yŏsung ŭi yŏkal", Asia yŏsŏng yŏn'gu 41 (2002) 269-313. 
Confucian dogma. Although holding funeral rites for a maternal grandfather could itself have been regarded as 'Buddhist behaviour', he nonetheless pushed ahead with his plan. Not satisfied even with that, he then performed another memorial ceremony in the traditional Buddhist manner. It is possible that Yi was comforted by the potentially magical effects of the Buddhist ritual. In any event, it is natural, given the political climate, that the second ritual was not recorded in any form and almost forgotten. However, it still reveals itself to us through the Buddhist material culture of the time, despite its absence from written documents.

According to the inscription, the patron offered Gathering of the Four Buddhas and two other paintings to the Sang'wŏn Monastery in Hamch'ang, the hometown of Kwŏn Ch'an. The second ancestral rite may have been held in the Sang'worn monastery, which was most probably the family temple for the Kwŏns of the Andong area, but was destroyed for unknown reasons between the sixteenth and eighteenth centuries. ${ }^{19} \mathrm{~A}$ man from the royal family using Buddhist paintings to honour his dead ancestor can be easily understood as a typical example of Buddhist patronage. However, given that the man caused a dispute over his mourning practice, the absence of written documents about his practice in Buddhism implies that it might have been hidden. In this regard, some artworks or relics for which no relevant documents exist may contain evidence of historical importance revealing the existence of practices or beliefs that did not follow prescribed regulations and that were therefore suppressed or hidden.

Religious beliefs and rituals are indispensable to each other. Thus, religious art reflecting actual domestic belief is often more closely related to ritual than to orthodox principles or texts. The inscription and iconography of Gathering of the Four Buddhas reveal that the intention of the patron was to mourn his late ancestor by holding a Buddhist ritual. This is a kind of domestic practice which was not written in the official records. Exploring rituals of the past by examining relics and religious objects from a modern perspective

19 Sinjŭng dongguk yŏjisŭngnam or The Revised and Augmented Survey of The Geography of Korea, printed in 1530, records Sang'won Monastery in Hamch'ang. However, after the eighteenth century, the monastery disappeared from maps and geography books. Sang'won Monastery might have been destroyed before the eighteenth century due to war or other upheavals. 
can illuminate hitherto unknown stories of Chosŏn Buddhist art. This paper is one such attempt.

\section{Bibliography}

Abe S.K., Ordinary Images (Chicago: 2002).

Bell C., Ritual Theory, Ritual Practice (New York: 1992).

Bell C., Ritual: Perspectives and Dimensions (New York: 1997).

Ch'oe C., “Chosŏn chŏn'gi chong'gyo honhap kwa panhonhapju'ǔi [Religious Syncretism and Anti-Syncretism of Confucianism, Buddhism, and Shamanism in the Earlier Half of the Chosŏn dynasty]", Chong'gyo yŏn'gu 27 (2007) 37-81.

Deuchler M., "Propagating Female Virtues in Chosŏn Korea", in Women in Confucian Cultures in Premodern China, Korea and Japan, ed. D. Ko - J.K. Haboush J.R. Piggott (Berkeley: 2003) 142-169.

Doniger W., Other Peoples' Myths: The Cave of Echoes (reprint, Chicago: 1995).

Han H., "Chosŏn chŏn'gi changne munhwa wa Kuihusŏ [Funeral Customs and Kuihusŏ in Early Chosŏn]", Chosŏn sidaesa hakbo 31 (2004) 39-78.

Kang H., "Chosŏn chŏn'gi pulgyo wa yŏsung'ŭi yŏkal [The Role of the Buddhist Women in the Early Chosŏn Dynasty]", Asia yŏsŏng yŏn'gu 41 (2002) 269-313.

Kim J., "The Patrons of Goryeo Buddhist Painting", The International Journal of Korean Art and Archeology 4 (2010) 32-61.

Kwŏn Kŭn, Yangch'onjip [Collected Works of Yangch'on] (Chinju, Kwŏn Ju: 1674; reprint, Seoul: 1978).

Pak Ŭ., Chosŏn chŏn'gi purhwa yŏn'gu [A Study on the Buddhist Painting of the Early Chosŏn Period] (Seoul: 2008).

Sŏ Gŏjŏng et al., Tongmunsŏn [Selected Writings of the Eastern Kingdom] (1478; reprint, Seoul: 1968).

Staal F., "The Meaninglessness of Ritual", Numen 26, 1 (1979) 2-22.

Stewart C. - Shaw R. (eds.), Syncretism/Anti-Syncretism: The Politics of Religious Synthesis (London: 1997).

Yi Y., "Samsebul ŭi hyŏngsik kwa kenyŏm pyŏnhwa [The Study on the Change of the Forms and Conceptions of 'Three Buddhas' of Chosŏn Dynasty]", Tong'ak misulsahak 9 (2008) 91-118.

Yu M., "Chosŏnjo ŭi t’aenghwa", in Kim Y., Chosŏn purhwa (Seoul: 1984) 188-204. 